The objectives outlined try to achieve the development of models that can be used as a basis for the design, optimization and scaling-up of photo-bio-reactors. In this sense, it is intended that the values of the parameters included in the models and its functionality with the different variables of the system do not depend on the reactor configuration.

\title{
Modelado matemático de la liberación controlada de fármacos desde dispositivos vaginales de tipo matriz monocapa con geometría de toro
}

\author{
Ignacio Marcelo Helbling \\ ihelbling@santafe-conicet.gov.ar \\ Julio Alberto Luna \\ María Inés Cabrera \\ INTEC I - CCT CONICET Santa Fe \\ Laboratorio de Química Fina \\ Facultad de Bioquímica y Ciencias Biológicas \\ Universidad Nacional del Litoral \\ Fecha de la defensa: 13/03/2013
}

\section{Resumen}

El diseño, desarrollo y el uso de los anillos vaginales han tenido creciente relevancia y atención en la ciencia, en la industria y en la sociedad en general. Esta tecnología está recién en sus inicios y se espera que en los próximos años tenga un rol preponderante en la industria farmacéutica. El empleo de un modelo matemático como herramienta para guiar el desarrollo y optimización de estos dispositivos de liberación controlada, es un factor clave en el avance y en el establecimiento de esta tecnología.

A este respecto, el desarrollo de un modelo matemático fiable capaz de predecir la cinética de liberación desde los anillos vaginales fue el objetivo central del presente trabajo. El modelo desarrollado se validó rigurosamente mediante comparación con perfiles experimentales obtenidos en nuestro laboratorio y con datos reportados en la bibliografía por otros autores. El uso de este modelo permite estudiar la liberación controlada de solutos desde los anillos mediante simulaciones computacionales, evitando así los inconvenientes propios de la experimentación in vitro e in vivo.

El modelo desarrollado se empleó con éxito para predecir la liberación de diversos solutos hormonales, abarcando en dicha tarea, la variación del polímero que conforma la matriz de los dispositivos, la variación de parámetros de diseño como la carga inicial de soluto y las dimensiones de los anillos, la variación de parámetros experimentales como la velocidad de agitación y el medio de liberación, entre otros. Los resultados exitosos obtenidos en este amplio rango de ensayos permiten aseverar la validez y utilidad del modelo desarrollado.

Finalmente, el modelo desarrollado se empleó con éxito para la optimización de un dispositivo comercial conocido. El uso del modelo posibilitó hacer comparaciones y estudios mediante simulaciones computacionales, que sentaron las bases para mejorar un anillo vaginal existente. Por todo ello, se puede concluir que el empleo del modelo matemático desarrollado es una herramienta invaluable en los procesos de 
diseño, fabricación y optimización de los dispositivos de liberación controlada con geometría de toro.

Mathematical modeling of controlled drug release from matrix-type torus-shaped vaginal devices

\section{Summary}

The design, development and use of vaginal rings have increased focus and attention in science, industry and society in general. This technology is still in its beginning and is expected to have an important role in the pharmaceutical industry in the coming years. The use of mathematical modeling as a tool to guide the development and optimization of these controlled release devices is a key factor in the progress and development of this technology.

In this regard, the development of a reliable mathematical model capable to predict the release kinetics from vaginal rings was the central goal of present study. The model developed was rigorously validated by comparison with experimental profiles obtained in our laboratory and with experimental data reported in the literature by other authors.
The use of this model allows to study the controlled release of solute from rings through computer simulations, thus avoiding the inconveniences of the in vitro and in vivo experimentation.

The model developed was successfully used to predict the release of different hormonal solutes, covering in this task, the variation of the polymer that forms the matrix of the devices, the variation of design parameters such as the initial load of solute and the dimensions of the rings, the variation of experimental parameters such as the agitation rate and the release medium, among others. The successful results obtained in this wide range of assays allow to asseverate the validity and usefulness of the model developed.

Finally, the model developed was successfully used for the optimization of an available commercial device. The use of the model allowed the study and the comparison of the system by computer simulations, which established the basis to improve an existing vaginal ring. Therefore, it can be concluded that the use of the mathematical model developed is an invaluable tool in the design, manufacture and optimization of torus-shaped controlled release devices.

\section{Estudio de la adsorción de compuestos biorrefractarios en solución acuosa}

\section{Pablo Danilo Húmpola}

phumpola@fbcb.unl.edu.ar

Dr. José Luis Vicente (INIFTA-CONICET-UNLP) Laboratorio de Investigación del Departamento de Química General e Inorgánica, FBCB-UNL. Instituto de Investigaciones Fisicoquímica Teóricas y Aplicadas-Área Fisi- coquímica de Superficies

Universidad Nacional de La Plata

Fecha de defensa: 11/10/2013

\section{Resumen}

En este trabajo se busca proponer nuevos puntos de vista sobre algunos de los 